\title{
顔料塗料印刷インキ＼cjkstart第三卷 第七號
}

\author{
[昭和四年七刀] \\ 成分を容器に明記することに就いて \\ 石 橋 正 樹 \\ I
}

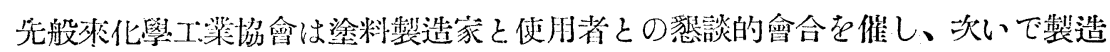

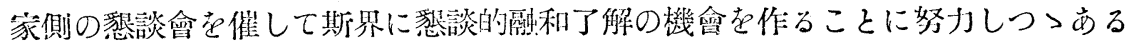
は誠にその勞を多とせざるを得ない。

第一次の會合に於いて趖築業者側上り六つの齐望的提笔があり、第二次の會合

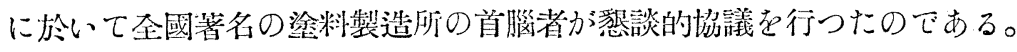

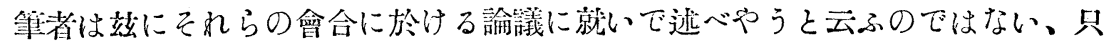
その提案中の最も主要なる「塗料成分を容器に朋訅する」ことに就いて洘虑する の機會を與へられたのでこっに思見を述べたいと思ふのである。

\section{II}

この希望的提案は次の如く解釋したい。

1）塗料䖵品程雜多にして使用に祭しその價值の制定賣擇に迷ふこと少くない 從つて簡單に製品孛識別し安心して使用し得るために。

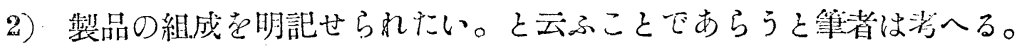

なるほぼ塗料の品程は極多て多く同一名棌のものもその內容效力に於いて格段 の相異があり、特に近時競争の激化々共に品質に於いても日々低下の偭向に在り そ稱せられて居る際のこととて、無理なら妨ことつ云はねねばならぬ。

III

然し乍ら成分を明訅することによつて果して完全に品質教制定することが出來 るかと云ふことをこつに問題とせね笈なら双。

製品たる塗料はその組成分原料の諸性質の總合的結果によつてその效力を發揮 するのであるから之れを朋記することによつて或程度迄品質を制定することが出

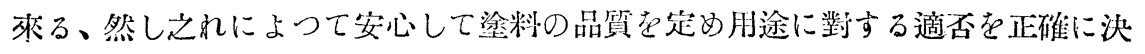
定し得るかと云ふのは大きな疑問てある。

IV

抑 塗料は組成分の割合のみによつてその價値一主として使用價値一をを決 
定することが出來るであらうか？

ウォルフ氏も云ふやうに、“塗料は化學的組成のみによつてその工栄的性:質は沈 定せられない”[Hans Wolfई, Farben Zeitung, 34, 12,723，(1928) ]のである、 侗一原料と踓もその扣工法、他の原料との配合法によつてその效果は谌しく相 異するのである。

化學技術者は製品の價值判定に際して己の最も得意とする所の化學分析に賴ら んとする、多くの場合之れは最も科學的であり正磼であり信賴するに足るもので ある、多くの化學製品が組成分及びそのパーセンテーデによつてその價值を制定 せられつつあることに就いて篎者は元より反對するものでない。

然し乍ら塗料に就いては化學分析郎ち組成分の沃定一一組成分に目万價值の判 定は極めて極限せられたる意義を有するものと考へられる。

\section{V}

この極限せられたる意義に於いて組成分に目る價值刺䇥が役机つものとしても 成分を明訅すると同時にその加工法を明訅することは價㯈の判䇥の上に於いて最

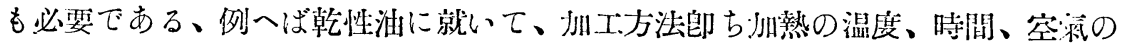
吹き达みの有然、タンキングの期间、乾燥劑の程頪、名秘、分量、添版法等等…

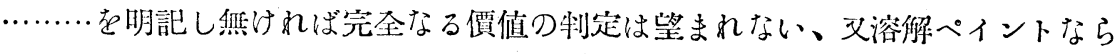

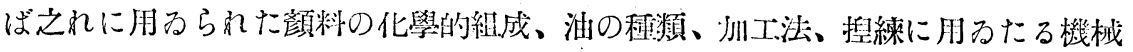
及びその程度、熔劑の物理的性質（之れは單に名峨を云ふのみで充分でない）、

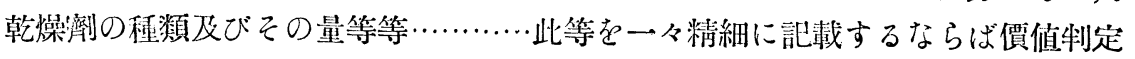
に於いて或程度の參考ともなるであらう。

然れども上訅の如き複雜な記載は各工場の特種技琎を曝露することであり又一 方使用者側に於いて一々之视精爻して了解し適確なる判斷ななるんとすれば、

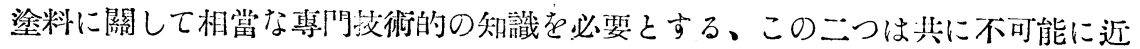
いこと〉云はねばならぬ、まして提案の趣意は簡單に品質を制定したいと云ふに 在ると考へられ然かも容器面に記載し得る程度のものであるとなれば合更のこと である。

\section{VI}

要するに容器に成分を明記して使用者側に於いて品質を制定するに便ならしめ んとすることは不可能のことと宩へられるのである。

塗料の品位は如何なる方法によつて制定すべきか? 化學的成分によつて制定は 可能であるか? 等等. の問題は今倚甲論乙の敬絕えざる所であり容器に成 分を明訅するが如きことは當分行はれるせず、また行つて見ても意義のあるもの とは考へられない。

塗料の品位。正碓に制定する方法如何はたらに使用者側のみの問題でなく、實 に亦製造家側に於ける難問題である。 (1929-6-18) 